\title{
Morphology of the first zoeal stage of Portunus acuminatus Stimpson, 1871 (Decapoda: Portunidae: Portuninae) reared in the laboratory
}

\author{
ROLAND MEYER ${ }^{1}$, INGO S. WEHRTMANN ${ }^{2}$ and ROLAND R. MELZER ${ }^{1}$ \\ ${ }^{1}$ Zoologische Staatssammlung, Münchhausenstr. 21, D-81247 München.E-mail: kld1129@mail.lrz-muenchen.de \\ ${ }^{2}$ Universidad de Costa Rica, Escuela de Biología, Museo de Zoología, 2060 San Pedro-San José, Costa Rica.
}

\begin{abstract}
SUMMARY: Larvae of Portunus acuminatus (Stimpson, 1871) from one female, collected by trawling at a depth of $12 \mathrm{~m}$ in the Gulf of Nicoya, Pacific Costa Rica, Central America $\left(090^{\circ} 48.899^{\prime} \mathrm{N}, 084^{\circ} 40.498^{\prime} \mathrm{W}\right)$ were hatched in the laboratory. The morphology of zoea I is described and illustrated for the first time and compared with known zoeae of other portunid species belonging to the subfamily Portuninae. We present a combination of three features which allows zoea I larvae of $P$. acuminatus to be distinguished from other described larvae of the genus. Descriptions are based on dissected larvae analysed by SEM and light microscopy.
\end{abstract}

Keywords: larval morphology, zoea, description, scanning electron microscope, Portunidae, Costa Rica.

RESUMEN: Morfología de la Primera zoea de Portunus aCuminatus (Stimpson, 1871) obTenida en el laboratorio. Se describe el primer estadio larvario del cangrejo Portunus acuminatus. Las larvas se obtuvieron en el laboratorio a partir de una hembra ovígera capturada en el Golfo de Nicoya (09048.899’N, 08440.498’W), Pacífico de Costa Rica. La descripción se ha realizado con la ayuda del microscopio electrónico de barrido y el microscopio óptico. Los caracteres morfológicos son comparados con los de otras especies de la subfamilia Portuninae. Presentamos una combinación de tres caracteres que permiten distinguir la primera zoea de $P$. acuminatus de otras larvas del género.

Palabras clave: morfología larval, zoea, SEM, Portunidae, Costa Rica, descripción.

\section{INTRODUCTION}

The swimming crab Portunus acuminatus (Stimpson, 1871) is a shallow water species distributed along the Pacific coast of America, from the Gulf of California (USA) to La Libertad (Ecuador). Sandy and/or muddy sediments are the habitat of $P$. acuminatus. Ovigerous females can be found from February to May (Garth and Stephenson, 1966).

The morphology of $P$. acuminatus zoeae has not been described yet. In the present study we describe and illustrate the first zoeal stage hatched in the laboratory and compare its morphology with described zoeae of other portunid species within the subfami- ly Portuninae. The study gives a detailed description of the larvae by analysing all morphological structures, by using a combination of SEM, light microscopy and dissection techniques. This includes an analysis of the inner, molar part of the mandibles with the SEM.

\section{MATERIALS AND METHODS}

Ovigerous females of $P$. acuminatus were trawled in April 2004 at a depth of $12 \mathrm{~m}$ in the Gulf of Nicoya, Pacific Costa Rica $\left(90^{\circ} 48.899^{\prime} \mathrm{N}\right.$, $\left.84^{\circ} 40.498^{\prime} \mathrm{W}\right)$. Individuals were transported to the 
laboratory of the Universidad de Costa Rica, San José, and held in separate aquaria containing filtered seawater at ambient temperature and salinity $\left(22 \pm 2^{\circ} \mathrm{C}, 33.0 \mathrm{psu}\right)$. The females were identified according to Garth and Stephenson (1966). Water was changed daily. Ovigerous females were not fed, and kept under these conditions until the larvae hatched.

Recently hatched larvae were removed from the vials and fixed in a graded ethanol series (30\%, 50\%, 70\%, 10 min. each) (see Meyer and Melzer, 2004). Fixed larvae were transported in August 2004 to the Zoologischen Staatssammlung München (Germany), where the SEM and light microscope preparation was done.

SEM preparation: fixed specimens were dehydrated in a graded acetone series $(70 \%, 80 \%, 90 \%$, $2 \times 100 \%, 10 \mathrm{~min}$. each). Larvae were either criticalpoint-dried in a Baltec CPD 030 or in HMDS (Hexamethyldisilazane) after Nation (1983) (see also Laforsch and Tollrian, 2000). After mounting on SEM stubs with self adhesive carbon stickers, individuals were dissected using a binocular and thin tungsten wires to make sure that all appendages were optimally orientated and separated for the scanning procedure. The dried specimens were coated with gold on a Polaron "Sputter Coater" and studied with a LEO 1430 VP SEM at $10-15 \mathrm{kV}$. To make sure that no setae on the appendages were removed or broken during the dissection, several appendages of each type were scanned and compared.

Light microscopy: ethanol fixed specimens were dissected in glycerine using a dissecting microscope and tungsten wires. For light microscopy, a Leica DM RBE and an Olympus SZX 12 equipped with a Visitron Spot Insight Colour digital camera were used.

It was not possible to dissect the complete set of appendages of a single, individual zoea. Therefore, many zoeae were prepared, and setae were counted from between 6 and 10 specimens of each type of appendage. The drawings of the maxillule and the maxilla were made with the aid of a camera lucida and then compared with the SEM data to analyse the different types of seta and smaller structures. For classification of the different types of setae we follow the terminology of Ingle (1992).

Measurements of the Zoea-I-larvae were done using LEO's SEM-User-Interface-Software. Carapace length (CL) was measured from the base of the rostrum to the posterior margin, carapace width $(\mathrm{CW})$ as the distance between tips of lateral spines, the total length (TL) from the base of the rostrum to the tip of the furca, dorsal spine length (DS) from the base of the dorsal spine to the tip, rostral length (RL) from the base of the rostral spine to its tip, and the rostrodorsal length (RDL) as the distance between the tip of the dorsal spine and the tip of the rostral spine. Measurements are based on a total of 10 larvae.

The female and zoeae of $P$. acuminatus were deposited at the Zoologische Staatssammlung München under the registration numbers ZSMA 20050130 for the adult and ZSMA 20050131 for the larvae.

\section{RESULTS}

\section{Description of the Zoea I}

Dimensions $[\mu \mathrm{m}]: \mathrm{RDL}=996.61 \pm 36.5, \mathrm{RL}=$ $293.14 \pm 6.7, \mathrm{DS}=427.1 \pm 18.5, \mathrm{TL}=1041.3 \pm$ $27.2, \mathrm{CW}=528.4 \pm 19.5, \mathrm{CL}=363 \pm 23.9$.

General Characteristics (Fig. 1A-C)

Compound eyes sessile (Fig. 1A, B). Dorsal organ in anterio-median region of the carapace (Fig. 1A, B). Carapace surface covered with tuberculettes (Fig. 1A, insert), with posteriorly curved smooth dorsal spine and lateral spines (Fig. 1A). Dorso-lateral region, between dorsal and lateral spine, with a pair of pappose setae (Fig. 1A, B). Anterior part of rostral spine with small denticles (Fig. 1A). Abdominal segments 2-5 with dorso-marginally located setae (Fig. 1B).

Carapace (Fig. 4A): Group of pore-like structures located in the dorso-median region (Fig. 4A). Two rows of pores posterior to dorsal spine; anterior row with 4 pores, posterior row with 2.2 pappose setae in the dorso-lateral region.

Antennule (Fig. 2A): Conical, unsegmented, with 2 aesthetascs and 2 single setae.

Antenna (Fig. 2A): Elongated spinous process bears on its proximal part setules (S) grading on the distal half in two rows of minute spines (D, inserts). Exopod unsegmented, with 2 terminal simple setae unequal in length.

Labrum (Fig. 4B): Posterior portion invested with numerous small denticulettes; labrum without setae.

Mandible (Fig. 4C, D): Left and right mandible dissimilar. Left mandible: outer margin of incisor process armed with 9 marginal spines; molar process a broad structure with 9 marginal and 2 sub- 

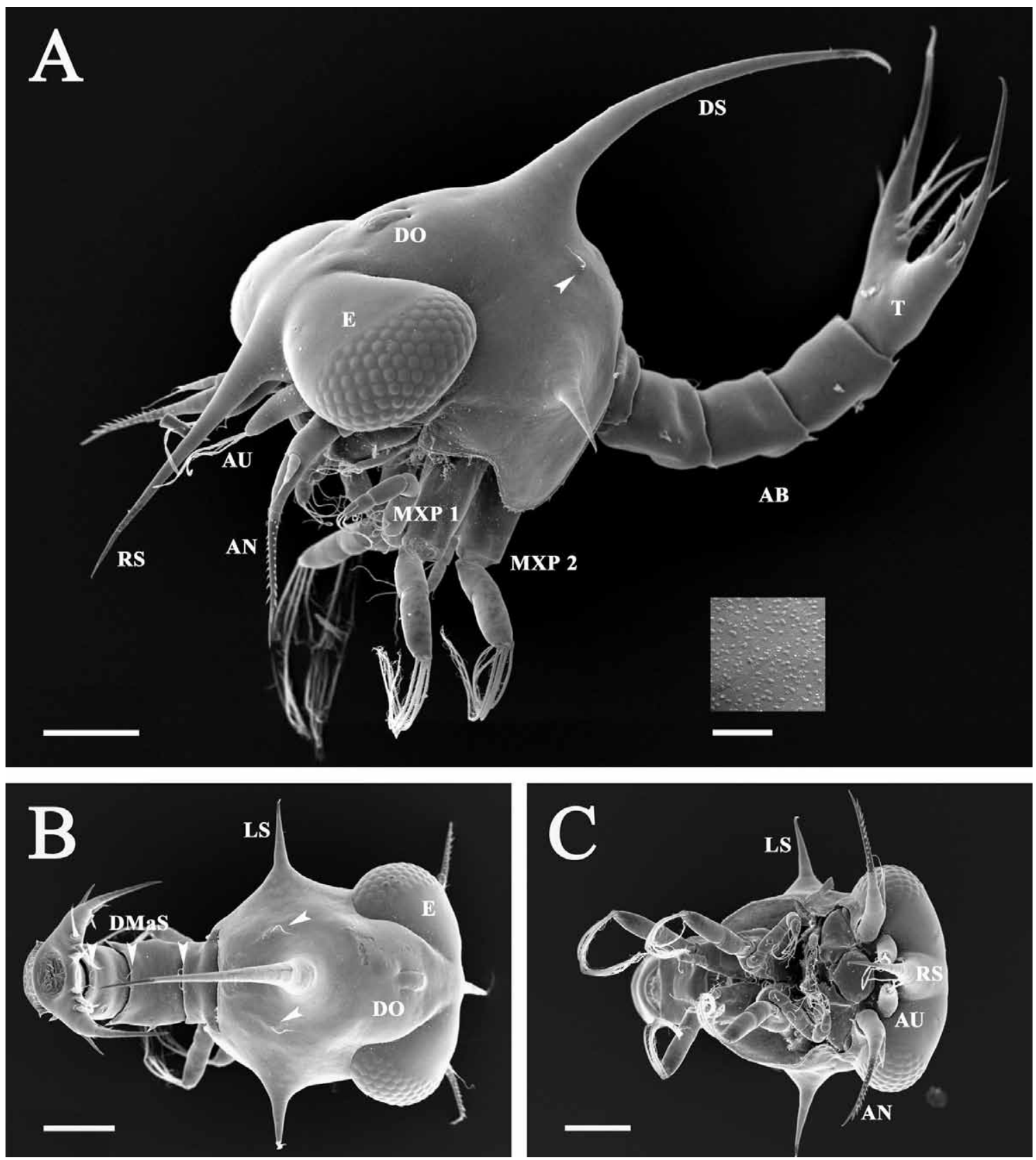

FIg. 1. - Portunus acuminatus, zoea I. - A general overview. A: Lateral view; insert shows carapace structure. B: Dorsal view. C: Ventral view. $A B$ : abdominal segments, $A N$ : antenna, $A U$ : antennule, $D O$ : dorsal organ, DMaS: dorso-marginal setae, $D S$ : dorsal spine, $E$ : eye, $L S$ : lateral spine, $M X P 1$ : first maxilliped, $M X P 2$ : second maxilliped, $R S$ : rostral spine, $T$ : telson. Arrows show setae in dorso-lateral region and dorso-marginal setae. All scale bars $100 \mu \mathrm{m}$, insert $10 \mu \mathrm{m}$.

marginal spines. Right mandible: incisor process with two acute protrusions, inner margin of molar process with 8 marginal spines.

Maxillule (Fig. 4E, 5A): Coxal endite unsegmented with 6 plumodendiculate setae and one subterminal simple seta (s). Endopod 2-segmented; 4 terminal setae (one simple seta (s) and 3 thin plumodenticulate setae) and 2 subterminal thin plumodenticulate setae; proximal segment unarmed.
Basial endite unsegmented; with one thin, subterminal plumodenticulate (p), two cuspidate (c) and two plumodenticulate $(\mathrm{p})$ setae; microtrichia located on inner margin.

Maxilla (Fig. 4F, 5B): Coxal endite bilobed, with $3+3$ plumodenticulate setae. Basial endite bilobed, with $4+4$ plumodenticulate setae. Endopod unsegmented, bilobed, with 2 long setae on proximal and 3 on distal lobe; long microtrichiae on both margins 

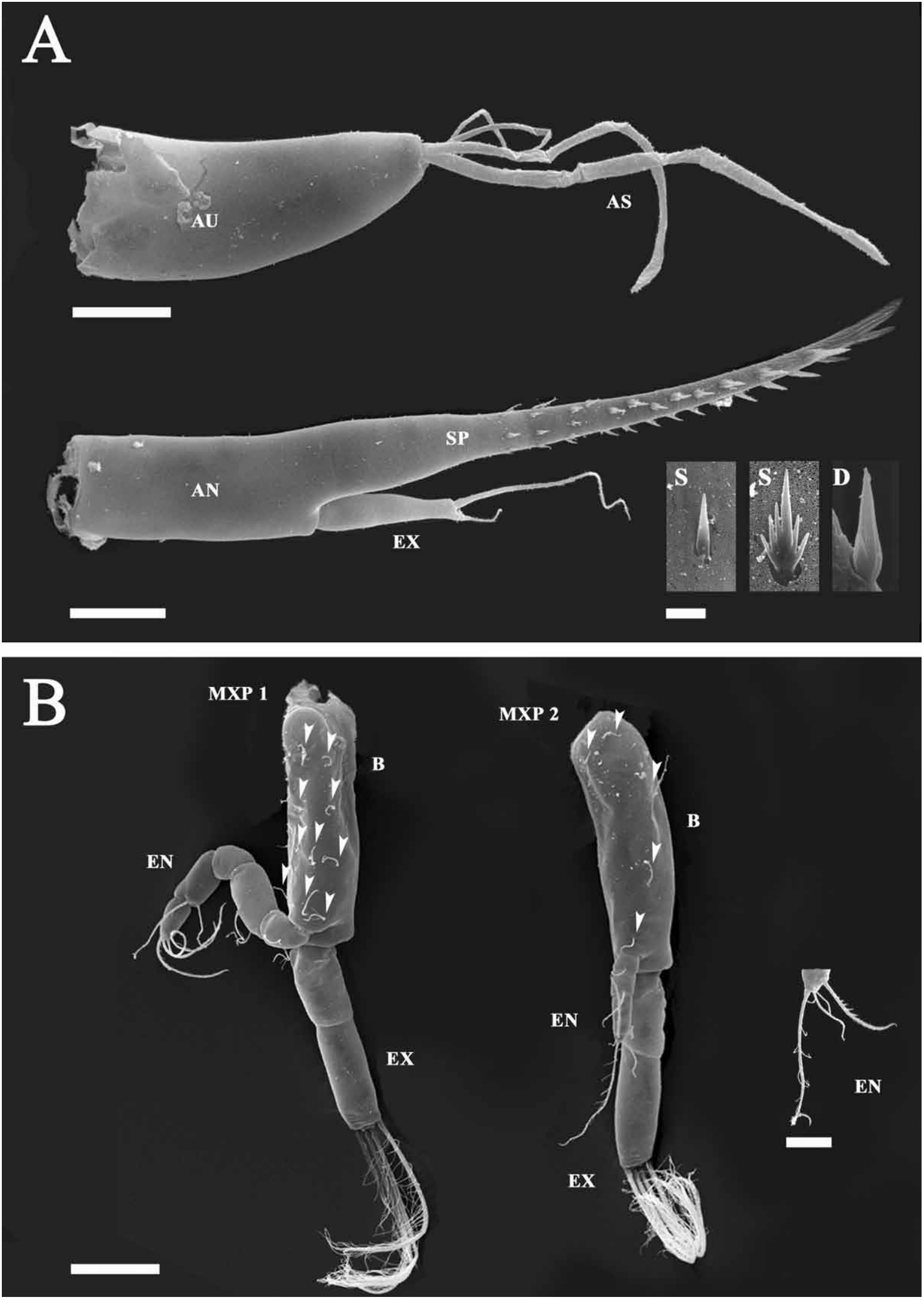

FIG. 2. - Portunus acuminatus, zoea I. - Appendages. A: Antennule (bar $20 \mu \mathrm{m}$ ) and antenna (bar $30 \mu \mathrm{m}$ ). Inserts: setules and denticles located on the spinous process of antenna (bar $2 \mu \mathrm{m}$ ). B: first and second maxilliped (arrows show setae arrangement on basis) (bar $60 \mu \mathrm{m})$ and distal part of endopod of maxiliped 2 (bar $20 \mu \mathrm{m}$ ). $A N$ : antenna, $A S$ : aesthetascs, $A U$ : antennule, $B$ : basis, $D$ : denticle, $E N$ : endopod, $E X$ : exopod, $M X P 1$ : first maxilliped, $M X P 2$ : second maxilliped, $S$ : setule, $S P$ : spinous process. 

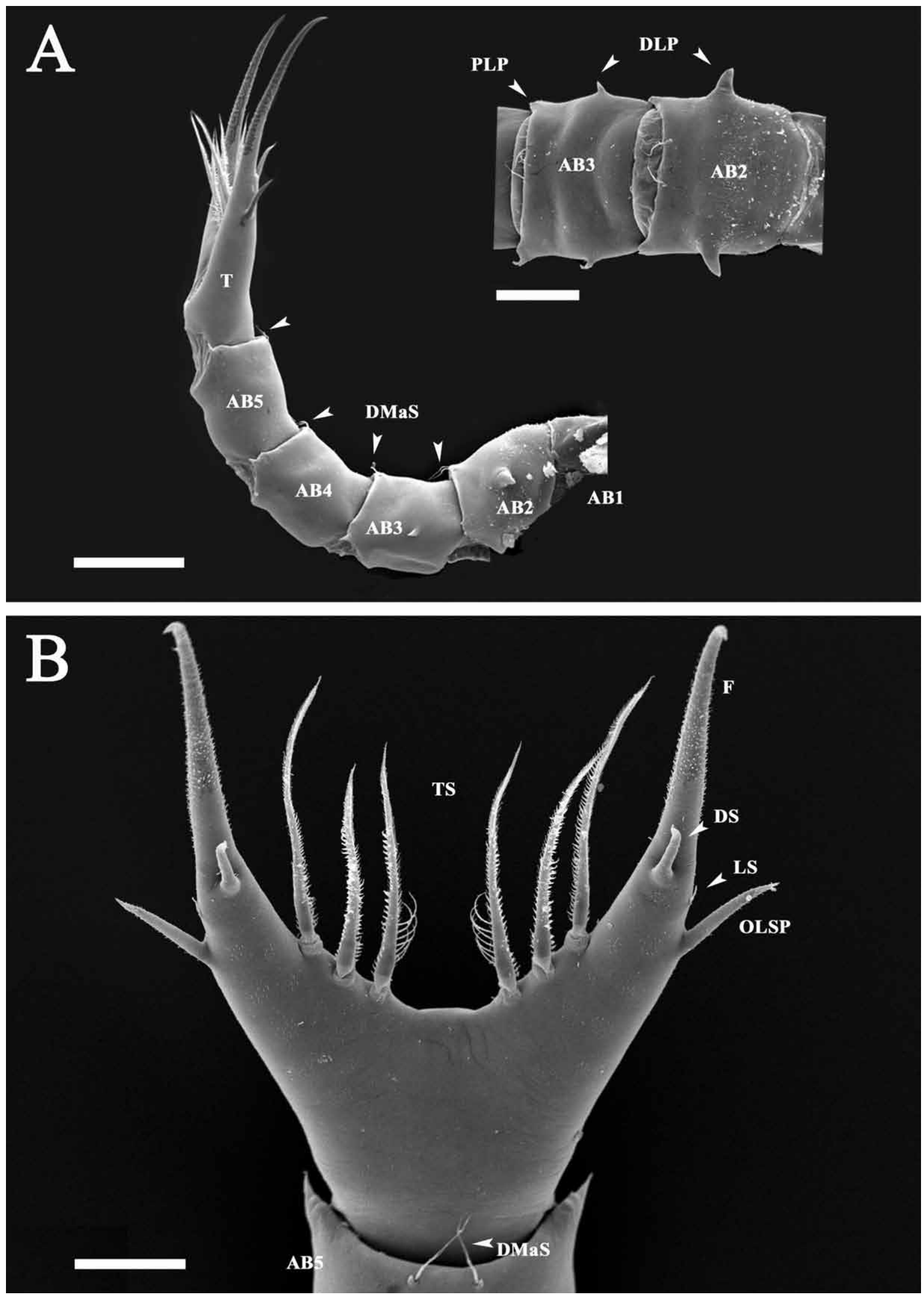

FIG. 3. - Portunus acuminatus, zoea I. - Appendages. A: Abdomen in lateral view (bar $100 \mu \mathrm{m}$ ) and abdominal segments 2-3 in dorsal view (bar $60 \mu \mathrm{m}$ ). B: Telson, dorsal view (bar $40 \mu \mathrm{m}$ ). AB: abdominal segments, DLP: dorso-lateral process, DMaS: dorso-marginal setae, $D S$ : dorsal spine, $F$ : furca, $L S$ : lateral spine, $O L S P$ : outer lateral spine, $P L P$ : posterior-lateral process, $T$ : telson, $T S$ : telson setae. 

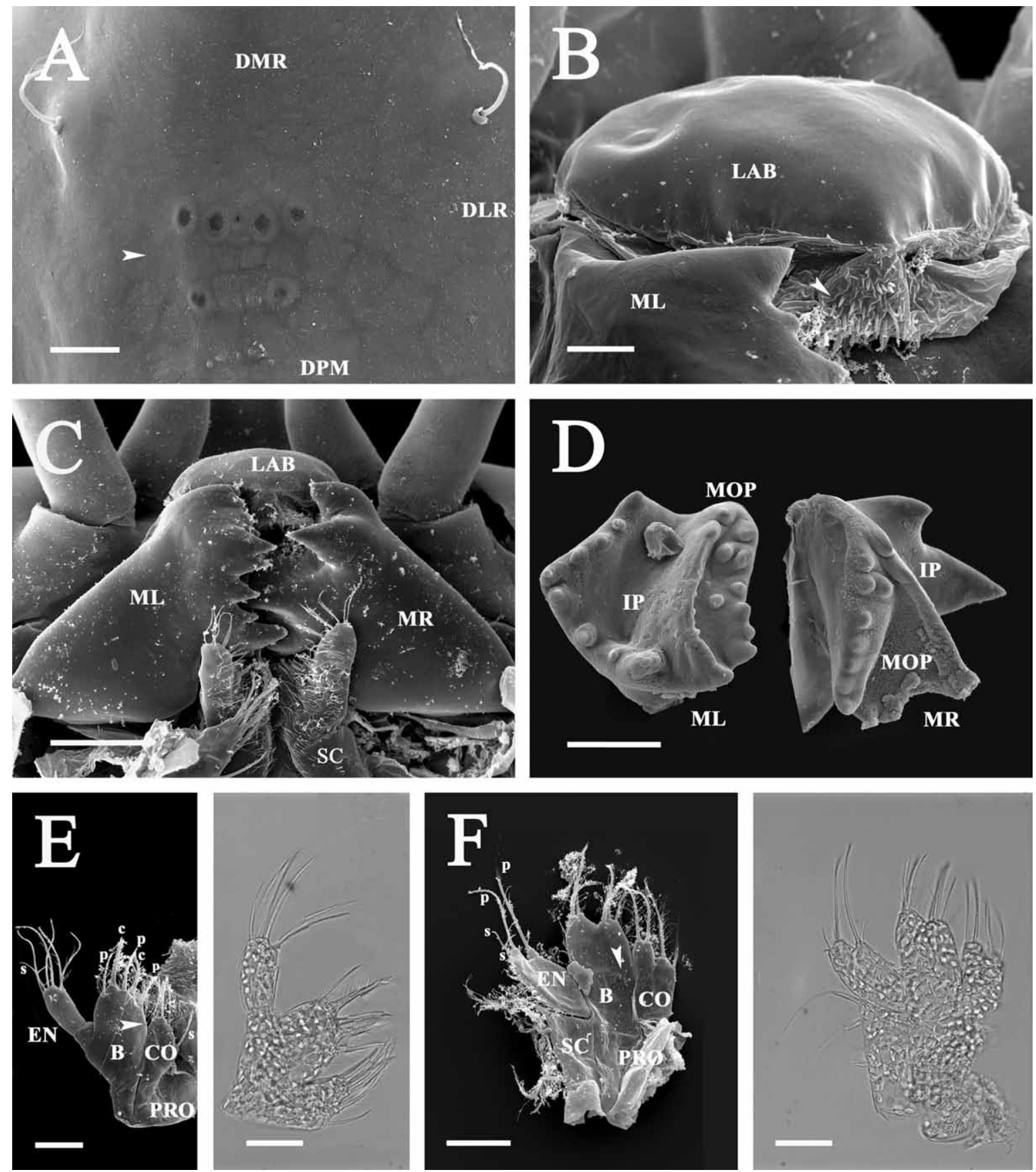

FIG. 4. - Portunus acuminatus, zoea I. - Appendages. A: carapace structure located at the dorso-median-region (bar $20 \mu \mathrm{m}$ ). B: Inner view on the labrum (bar $10 \mu \mathrm{m}$ ). C: Mandibles orientated in the zoea (maxillule and maxilla removed) (bar $40 \mu \mathrm{m}$ ). D: Inner view of the surface on dissected mandibles (bar $70 \mu \mathrm{m}$ ). E: Ventral view on the left maxillule; SEM and light microscope (bar $30 \mu \mathrm{m}$ ). F: Inner view of the right maxilla; SEM and light microscope (bar $30 \mu \mathrm{m}$ ). Arrows show microtrichia. $B$ : basial endite, $c$ : cuspidate seta, $C O$ : coxal endite, $D L R$ : dorsolateral region, $D M R$ : dorso-marginal region, $D P M$ : dorso-posterior margin, $E N$ : endopod, $I P$ : incisor process, $L A B$ : labrum, $M L$ : left mandible, $M O P$ : molar process $M R$ : right mandible, $p$ : plumodenticulate seta, $P R O$ : protopod, $s$ : simple seta, $S C$ : scaphognathite

of the endopod. Scaphognathite (exopod) with 4 plumose marginal setae and a long distal stout process.

First maxilliped (Fig. 2B): Coxa without setae. Basis with 10 medial simple setae arranged $2+2+3+3$ on inner side. Endopod 5-segmented, with 2,2,0,2,5 (1 subterminal and 4 terminal) sparsely plumose setae. Exopod 2-segmented; distal segment with 4 long plumose natatory setae.

Second maxilliped (Fig. 2B): Coxa without setae. Basis with 5 single setae arranged $2+1+1+1$. Endopod 3-segmented, with 1,1,5 (2 plumodenticulate and 3 single setae). Exopod 2-segmented, distal segment with 4 plumose natatory setae. 

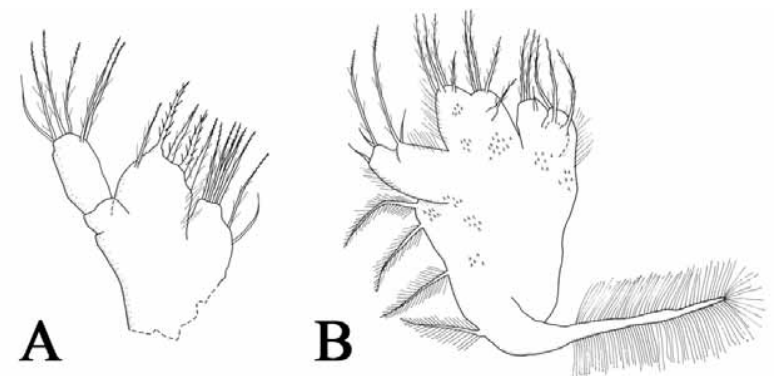

FIG. 5. - Portunus acuminatus, zoea I. A: maxillule (ventral view), B: maxilla (inner view).

Abdomen (Fig. 3A): 5-segmented; segments 2-5 with dorso-marginally located pair of single setae; segments 2 and 3 with dorso-lateral processes; segments 3-5 with posterio-lateral processes.

Telson (Fig. 3B): Posterio-external margins extended into furcae; inner margin with 6 plumodenticulate setae; the two innermost with broad medial setules; distal part of each branch with small denticles; each branch of furca with outer spines on proximal third.

\section{DISCUSSION}

The present description of $P$. acuminatus zoeae is based on a combination of SEM and light microscopical techniques applied to fixed larvae and dissected appendages. The advantage of this combination of techniques is that even minute setules or spines can be located and analysed using the SEM (e.g. Meyer et al. 2004). In addition, the threedimensional structure of mouthparts can be studied in detail. However, it was not possible to get a complete SEM-preparation of the maxillule and the maxilla. Therefore light microscopy was used for an overview and SEM data were used for details to produce complete drawings of these two mouthparts.

Another advantage of our combined technique seems to be the fact that we could analyse in detail the inner part of the mandibles with the SEM. Ingle (1992) mentions that the left and right mandible in zoeae are usually slightly dissimilar and that details are not easy to resolve by light microscopy due to their gross three-dimensional structure. Using SEM combined with dissection allows a thorough analysis of mandibular structures, as shown by Greenwood and Fielder (1979) who described the mandibles of Portunus rubromarginatus using SEM. A comparison of the mandibular structures of
$P$. rubromarginatus and $P$. acuminatus revealed differences between the species; thus, such analyses could give access to a relevant, and yet poorly studied set of characters for larval diagnosis.

\section{Comparison of portunid zoeae}

The family Portunidae Rafinesque, 1815, includes the following six subfamilies: Carcininae Macleay, 1838, Polybiinae (syn. Macropininae) Ortmann, 1893, Portuninae Rafinesque, 1815, Catoptrinae Borradaile, 1903, Caphyrinae Paul'son 1875 and Podophthalminae Dana, 1851 (Stephenson and Campbell, 1960). Larvae of only the first three of these were known when Rice and Ingle (1975) sought to survey their knowledge on portunid zoeae. They found distinctive features between the zoeae of the Carcininae, Polybininae and Portuninae subfamilies based on the presence or absence of carapace lateral spines, the number of abdominal segments with dorsolateral projections, the length of the posterio-lateral processes of abdominal segments 3 and 4 , the telson fork armature, the number of setae of the telson's posterior border, and the armature of the middle segment of the endopod of the first maxilliped. Two of these characters can be studied in Zoea-I-larvae: (i) Carapace lateral spines are well developed in Polybiinae and Portuninae, but not in Carcininae. (ii) The middle segment of the endopod of the first maxilliped is armed in Polybiinae and unarmed in Portuninae (Rice and Ingle, 1975).

The morphological characters analysed in the present study correspond well with the subfamilial larval characters for the Portuninae established by Rice and Ingle (1975): (1) lateral carapace spines are well developed, (2) dorso-lateral projections are found on abdominal segments 2 and 3, (3) abdominal segments 3 to 5 bear posterior lateral processes, (4) the telson fork spine number is similar and (5) there is an unarmed endopod middle segment at the first maxilliped.

Since the publication of Rice and Ingle (1975) the larval stages of several species of Portuninae have been described, e.g. Callinectes sapidus, (Costlow and Bookhout, 1966), Charybdis acuata, (Kurata and Omi, 1969), Portunus spinicarpus, (Bookhout and Costlow, 1974), Portunus gibbesii, (Kurata, 1970), Scylla serrata, (Wear and Fielder, 1985), Callinectes similis, (Bookhout and Costlow, 1977), Portunus rubromarginatus, (Greenwood and Fielder, 1979), Portunus pelagicus, (Shinkarenko, 


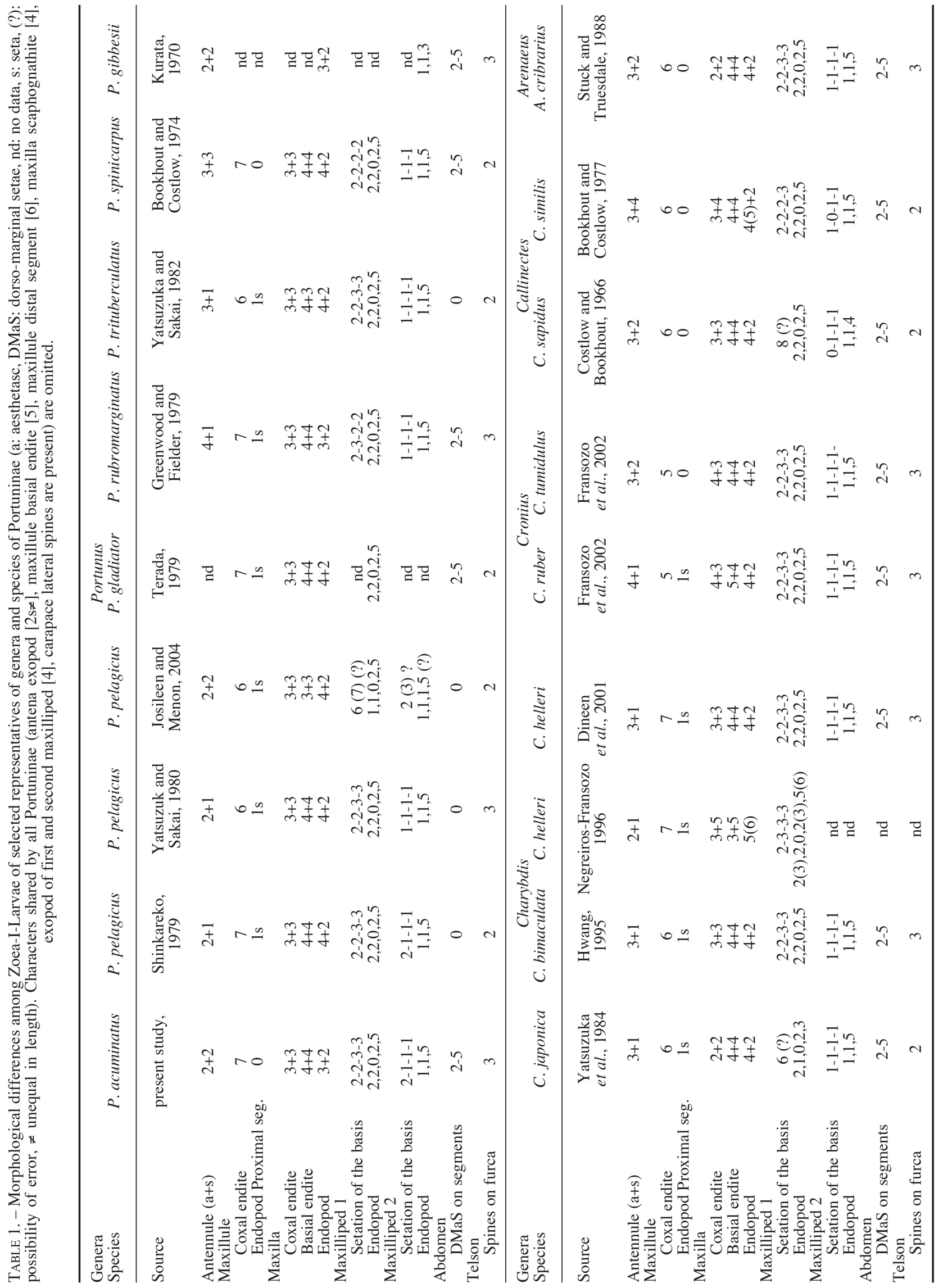


1979), Portunus gladiator, (Terada, 1979), Thalamita danae, (Fielder and Greenwood, 1979), Charybdis callianassa, (Greenwood and Fielder, 1980), Portunus pelagicus, (Yatsuzuka and Sakai, 1980), Portunus trituberculatus, (Yatsuzuka and Sakai, 1982), Charybdis japonica, (Yatsuzuka et al., 1984), Arenaeus cribrarius, (Stuck and Truesdale, 1988), Thalamita prymna, (Terada, 1986), Thalamita crenata, (Krishnan and Kannupandi, 1990), Charybdis bimaculata, (Hwang, 1995), Charybdis helleri, (Negreiros-Fransozo, 1996), Callinectes danae, (Sankarankutty et al., 1999), Charybdis helleri, (Dineen et al., 2001), Cronius ruber and C. tumidulus, (Fransozo et al., 2002) and Portunus pelagicus, (Josileen and Menon, 2004).

To include our findings in a generalised view on Portuninae zoeae and to find diagnostic features for $P$. acuminatus, we summarised the different morphological characters of Zoea-I-larvae of Portuninae (Table 1). It is concluded that all the described ZoeaI-larvae of this subfamily [Portuninae] share the following characteristics: (1) number of setae of the antenna exopod [2, unequal], (2) number of setae of the maxillula endopod [4 +2], (3) the number of setae of scaphognathite of maxilla of the first zoea is 4 , as in all non-majid zoeas, (4) unarmed middle segment of the endopod of the first maxilliped, (5) number of setae of maxilliped 2 [1-1-5, except Callinectes sapidus: 1-1-4], (6) number of natatory setae of exopods of maxilliped 1 and 2 is 4 as in all brachyuran zoeae, (7) presence of carapace lateral spines, (8) dorso-lateral processes on abdominal segments 2 and 3 . These characteristics confirm the subfamily-classification established by Rice and Ingle (1975).

The distinction between the different subfamilies seems to be well established within the Portuninae. However, the comparison of the morphological characteristics of representatives of the four genera Arenaeus, Callinectes, Cronius and Portunus (Table 1) indicates that within the subfamily Portuninae all larvae have a very similar morphology that makes a diagnosis at the generic level based only on morphological data of the first zoeal stage impossible at the moment. Hence, using a combination of morphological and other characteristics like chromatophorepatterns, mandible structure and a comparison including all zoeal stages might lead to results (e.g. Terada, 1979). In addition, intraspecific variability hinders species distinction, as has been shown for $P$. pelagicus and Charybdis helleri, where differences between the setal numbers of various appendages and the telson morphology occur depending on the region of origin of the samples (Shinkarenko, 1979; Yatsuzuka and Sakai, 1980; Josileen and Menon, 2004). Stephenson (1972) explained this by the presence of undetected clines and subspecies (see also Meyer et al., 2004). Furthermore, even larvae from the same location show differences (Wehrtmann and Albornoz, 1998; 2003).

\section{Distinctive features of $\boldsymbol{P}$. acuminatus zoeae}

Nevertheless we found "good candidates" for species-specific features of $P$. acuminatus zoeae that have to be checked when new descriptions of other Portunus zoeae become available. At the present the Zoea-I-stage of $P$. acuminatus can be characterised and distinguished from other described larvae of the genus Portunus by the combination of the following three features: (1) absence of a seta on the proximal endopod segment of the maxillule, (2) the endopod setation of the maxilla and (3) the telson fork armature. As can be seen in Table 2, these features are also found in some other Portunus species, but not in this combination.

In addition, the larvae of $P$. acuminatus have two conspicuous carapace structures not well known in other portunid zoeae: the dorsal organ, located in the anterior median region and a cuticular pore organ located in the dorso-median region. The ultrastructure of the dorsal organ of other Decapoda is discussed in several papers (e.g. Laverack et al., 1996). We observed the presence of the posteriorly and dorsally situated organs in Zoea-I-larvae of different decapods (Meyer, pers. obs.). The presence or absence of these organs and their structure might become a useful character for larval diagnosis and also important for future phylogenetic studies.

\section{ACKNOWLEDGEMENTS}

This paper was written as part of cooperation (UCR-VI Project No. 808-A4-757) between the Universidad de Costa Rica (UCR) and the Zoologische Staatssammlung München (ZSM). We wish to thank the Centro de Investigación en Ciencias del Mar y Limnología (CIMAR) for providing us the rearing facilities and supporting us during the collection excursions. Special thanks go to Stefan Friedrich (Munich) for collection manage- 
ment of the specimens and the "Freunde der Zoologischen Staatssammlung e.V." for supporting us with a grant for lab equipment. Furthermore, we would like to acknowledge Rita Vargas of the Museo de Zoología, Escuela de Biología, UCR, for helping us with the determination of the collected material, and Katharina Jörger (Munich) for providing us with the maxilla drawings. We are also thankful to two referees and Fernando Mantelatto for their valuable comments, which greatly improved the manuscript.

\section{REFERENCES}

Bookhout, C.G. and J.D. Costlow. - 1974. Larval development of Portunus spinicarpus reared in the laboratory. Bull. Mar. Sci., 24: 20-51.

Bookhout, C.G. and J.D. Costlow. - 1977. Larval development of Callinectes similis reared in the laboratory. Bull. Mar. Sci., 27: 704-728.

Costlow, J.D. and C.G. Bookhout Jr. - 1966. Larval development of Callinectes sapidus Rathbun reared in the laboratory. Biol. Bull. (Woods Hole, Mass.)., 116: 373-396.

Dineen, J.F., P.F. Clark, A.H. Hines, S.A. Reed and H.P. Walton. 2001. Life history, larval description, and natural history of Charybdis helleri (Decapoda, Brachyura, Portunidae), an invasive crab in the Western Atlantic. J. Crust. Biol., 21: 774-805.

Fielder, D.R. and J.G. Greenwood - 1979. Larval development of the swimming crab Thalamita danae Stimpson 1858 (Decapoda, Portunidae) reared in the laboratory. Proc. R. Soc. Queensland, 90: 13-20.

Fransozo, A., F.L.M. Mantelatto and G. Bertini. - 2002. The first zoeal stage of the genus Cronius (Brachyura, Portunidae) from the Brazilian coast, hatched in a laboratory. J. Plankton Res., 24: 1237-1244.

Garth, J. and W. Stephenson. - 1966. Brachyura of the Pacific Coast of America Brachyrincha: Portunidae. Allan Hancock Fundation Monographs in Marine Biology. Allan Hancock Foundation, University of Southern California, Los Angeles, California

Greenwood, J.G. and D.R. Fielder. - 1979. The zoeal stages and megalopa of Portunus rubromarginatus (Lanchester) (Decapoda: Portunidae), reared in the laboratory. J. Plankton Res., 1: 191-205.

Greenwood, J.G. and D.R. Fielder. - 1980. The zoeal stages and megalopa of Charybdis callinassa (Herbst) (Decapoda: Portunidae), reared in the laboratory. Proc. Royal Soc. Queensland., 91: 61-76.

Hwang, S.G. - 1995. Complete larval development of the swimming crab, Charybdis bimaculata (Miers, 1886) (Crustacea, Brachyura, Portunidae), reared in laboratory. Korean J. Zool., 38(4): 465-482.

Ingle, R.W. - 1992. Larval Stages of Northeastern Atlantic Crabs. Chapman and Hall. London, New York, Tokyo, Melbourne, Madras.

Josileen, J. and N. Menon. - 2004. Larval stages of the blue swimmer crab, Portunus pelagicus (Linnaeus, 1758) (Decapoda, Brachyura). Crustaceana, 77(7): 769-896.

Krishnan, T. and T. Kannupandi - 1990. Laboratory cultured zoea, megalopa and first crab of the estuarine crab Thalamita crenata (Latr.) A. Milne Edwards 1861 (Brachyura: Portunidae). Mahasgar, 23(2): 139-152.

Kurata, H. - 1970. Studies on the life histories of decapod Crustacea of Georgia: Part III. Larvae of decapod Crustacea of Georgia. Final Report. University of Georgia Marine Institution, Sapelo Island, Georgia.
Kurata, H. and H. Omi - 1969. The larval stage of a swimming crab, Charybdis acuata. Bull. Tokai Reg. Fish. Res. Lab., 57: 129-136.

Laforsch, C. and R. Tollrian. - 2000. A new preparation technique of daphnids for Scanning Electron Microscopy using hexamethyldisilazane. Arch. Hydrobiol., 149: 587-596.

Laverack, M.S., D.L. MacMillan, G. Ritchie and S.L. Sandow. 1996. The Ultrastructure of the sensory dorsal organ of Crustacea. Crustaceana, 69(4): 636-651.

Meyer, R. and R.R. Melzer. - 2004. Scanning EM diagnosis of marine Decapoda larvae: A comparison of preparation techniques. Crustaceana, 77: 883-886.

Meyer, R., S. Friedrich and R.R. Melzer. - 2004. Xantho poressa (Olivi, 1792) and Xantho pilipes A. Milne-Edwards, 1867 larvae (Brachyura; Xanthidae): Scanning EM diagnosis. Crustaceana, 77: 997-1005.

Nation, J.L. - 1983. A new preparation method using hexamethyldisilazane for preparation of soft insect tissues for scanning electron microscopy. Stain Technol., 58: 347-351.

Negreiros-Fransozo, M.L. - 1996. The zoea I of Charybdis helleri (A. Milne-Edwards, 1867) (Decapoda, Portunidae) obtained in laboratory. Nauplius, 4: 165-168.

Rice, A.L. and R.W. Ingle. - 1975. A comparative study of the larval morphology of the British portunid crabs Macropipus puber (L.) and M. holsatus (Fabricius), with a discussion of generic and sub-familial larval characters within the Portunidae. Bul. British Mus. (Nat. Hist.) Zool., 28(4): 121-151.

Sankarankutty, C., S.Y. Hong and K.B. Kim. - 1999. Description of laboratory reared first zoea of Callinectes danae (Crustacea, Decapoda, Portunidae). Rev. Bras. Zool., 16(suppl.2): 45-49.

Shinkarenko, L. - 1979. Development of the larval stages of the blue swimming crab Portunus pelagicus L. (Portunidae: Decapoda: Crustacea). Aust. J. Mar. Freshwater Res., 30: 485-503.

Stephenson, W. and B. Campbell. - 1960. The Australian portunids (Crustacea: Portunidae). IV. Remaining genera. Aust. J. Mar. Freshwater Res., 11: 73-122.

Stephenson, W. - 1972. An annoted check list and key to the Indowest-Pacific swimming crabs (Crustacea: Decapoda: Portunidae). Ray. Soc. New Zealand Bull., 10: 1-64.

Stuck, K.C. and F.M. Truesdale. - 1988. Larval development of the speckled swimming crab, Arenaeus cribrarius (Decapoda, Brachyura, Portunidae) reared in the laboratory. Bull. Mar. Sci., 42: $101-132$

Terada, M. - 1979. A classification of zoea larvae in the subfamily Portuninae of the family Portunidae. Zool. Mag. (Tokyo), 88(3): 254-268.

Terada, M. - 1986. Zoeal development of the swimming crab Thalamita prymna (Herbst); Portunidae, Portuninae. Researches on Crustacea, 15: 15-23.

Wear, R.G. and D.R. Fielder - 1985. The marine fauna of New Zealand: larvae of the Brachyuran (Crustacea, Decapoda). N.Z. Ocean. Inst. Mem., 92: 1-89.

Wehrtmann, I. S. and L. Albornoz. - 1998. Larval development of Nauticaris magellanica (A. Milne Edwards, 1891) (Decapoda: Caridea: Hippolytidae), reared under laboratory conditions. Bull. Mar. Sci., 62(1): 45-72.

Wehrtmann, I. S. and L. Albornoz. - 2003. Larvae of Nauticaris magellanica (Decapoda: Caridea: Hippolytidae) reared in the laboratory differ morphologically from those in nature. J. Mar. Biol. Assoc. U.K., 83: 949-957.

Yatsuzuka, K. and K. Sakai. - 1980. The larvae and juvenile crabs of Japanese Portunidae (Crustacea, Brachyura): I Portunus (Portunus) pelagicus (Linne). Rep. Usa Mar. Biol. Inst., 2: 25-41.

Yatsuzuka, K. and K. Sakai. - 1982. The larvae and juvenil crabs of Japanese Portunidae (Crustacea, Brachyura): II Portunus (Portunus) trituberculatus (Miers). Rep. Usa Mar. Biol. Inst., 4: 9-26.

Yatsuzuka, K., K. Sakai, N. Del and R. Roman. - 1984. The larvae and juvenile crabs of Japanese Portunidae (Crustacea, Brachyura): III. Charybdis japonica, A. Milne Edward. Rep. Usa Mar. Biol. Inst., 6: 23-40.

Scient. ed.: E. Macpherson

Received May 16, 2005. Accepted October 25, 2005. 